\title{
The Study of Historical Origins and Architectural Structure of Crypt-like-Tombs Family (Lahad) in Khoramabad
}

\author{
Mohammad Mehdi Tavassoli ${ }^{1}$ \\ Sina Tavassoli2 \\ Mohammad Mirzaei Rashnoo ${ }^{3}$ \\ Mohammad Mohammadi As/ ${ }^{4}$ \\ ${ }^{1}$ Corresponding Author; Associate Professor, Department of Archaeology, University of Sistan \& Balochestan, Zahedan-Iran \\ Email: mohamadmehditavasoli@yahoo.com \\ 2Ph.D. scholar, Department of English Language and Literature, JMI University, New-Delhi, India \\ ${ }^{3}$ M.A.Archaeology \\ 4Lecturer, Dxepartment of Architecture, Elmi-Karbordi University, Khoramabad, Iran
}

\section{Doi:10.5901/mjss.2016.v7n4p}

\begin{abstract}
The family crypt in the main cemetery of Khoramabad, which is also known as Khizr, located in province of Lorestan demonstrates a kind of funeral which is especially related to paternal members. This model of burial was dated back to historical era in Iran and it has probably rooted in Zoroastrian tradition. Nonetheless, there is very few information about the method of burial in the secondary materials and people do not have enough information and detail in this regard. However, the necessity of this research is relevant. With respect to such importance the main questions which is needed to be researched are when did construction of Lahad start in Khoramabad and what was its social implementation, and on which basis its structural architecture was constructed. In order to reach at justified results, this research utilizes an investigation in secondary sources and field work and identification of available Lahads in cemetery of Khoramabad as well as a tour trip to different cities in Lorestan and Khozistan for further exploration. Then, an analysis of data with a chart of Lahads of Khizr has carried out to compile this article. This research with the help of field work aims to shed light on the origins of Lahad tradition and its social implementation and characteristics of its architectural structure.
\end{abstract}

Keywords: Lahad (family tomb); Khoramabad Cemetry; Lorestan; Iran.

\section{Introduction}

Khoramabad is the capital of Lorestan, located in west part of Iran. This city is one of the oldest cities of Iran, which is renowned because of its historical monuments and ancient sites. The famous and ancient cemetery of this city known as Khizr with its family crypt-like-tombs (catacomb/charnel house) has turned into exciting visiting place as well as a remarkable site for research. In this cemetery, there are crypts in which the way of burial is carried out with a special method related to patriarchy. This method of burial seems has been performed in historical era in Iran and possibly traces back to Zoroastrian tradition. Whereas few details are available about such burial method in written books as well as lack of people's information, thus the necessity of research in this topic is justified. With respect to such necessity, the authors of this paper reached to the point to form a hypothesis in which the method of burial has adapted from ancient Iranian traditions and in particular probably from Zoroaster beliefs, which followed by some changes during the times and performed in Khoramabad at Khizr cemetery for centuries. However, the authors have tried to investigate and revisiting available secondary materials in order to find a way for research regarding this topic. The main objectives of this research are consisted of:

When does the tradition of construction of Lahad (crypt-like-tombs) start in Khoramabad?

What was the social function of Lahad?

How was the architectural arrangement/structure of Lahad based upon?

The methodology applied in this research is included of the following points:

1. Investigation in secondary sources: There is no manuscript available or written on this subject and any real source to hint to Lahad will not found. So, we had to go through the secondary sources to collect adequate 
information on the main subject.

2. Tour trip to different cities: To find more information, more evidence and collecting more samples, we took a tour trip to different cities around of Khorramabad, and also we went to Khozistan province which is located in south part of Lorestan province.

3. Data Analysis: Finally, with the help of analyzing data, we found an answer to the article hypothesis.

However, before starting to achieve anything, we, the authors, accepted this method which could give the best answers to our questions concerning the subject.

To find reasonable answers to the raised questions, a survey in field work is decided to be carried out in Lorestan and some part of Khozistan province which is culturally supposed under the influence of Lorestan. Next, crypt-like-tombs of khizr and their similar ones in suburb of Khoramabad were explored. Regarding such tradition and the reason of their continuity until now, some talks initiated with the families and owners of these Lahads. Therefore, to reach a comprehensive result, data analysis and discussion have carried out. A table about available Lahads and their grave stones is also added to help next researchers to the goals of this article.

\section{Research Background}

Discussion on historical roots and architectural structure of crypt-like-tombs of Khoramabad is one of the original research subjects which has not been researched and explored so far in written sources, secondary materials and field works. Until now, there are only two concise and incomplete articles which are dealt with this subject. Rastegardfard (2004) in his article titled "Cemeteries and Mourning in Lorestan", briefly has referred to Crypt-like-tombs of Lorestan and their architecture and the way how the burial ceremony performed. He believed that this tradition of burial service is related to ancient Iran and to prove this claim he referred to the found excavations of ancient sites in respect with Achaemenian and Medes (Rastegarfard, 2004). He published this article in his official website. The other article entitled "Aristocratic Graves of Bronze Age in Gilvaran, Khoramabad", written by Ahmad Parviz and Pourya Khadish published in Research Journal of Archaeology (2012). This article only concentrates on cultural objects which are found in crypts of Gilvaran and their locations in Lorestan, but no explanations has been offered about their social function, architecture and the way of burial service (Parviz and Khadish, 2012: 110-111; Jaavid, 1990; Mohamadi, 2010). In conclusion to the article, they emphasized that the construction of such collective graves or Lahads stopped by the end of the third millenniums (Parviz and Khadish, 2012: 112).

Nevertheless, the present article can be understood as the first research field work in which a precise survey has done on Lahads or family crypts in Khoramabad, thus this paper is peculiar. In fact, the significant of this paper is based upon its updated scientific methods which are dealt with for the first time.

\section{The Background of Family Burial Chambers in Iran}

There have been different kinds of burial services in the vast and ancient land of Persia as every period had a specific ritual for burial. For instance, there was no cemetery in Neolithic and Chalcolithic and most of burial used to be done in floor of the houses. It was only in the Bronze Age which cemeteries came into being outside the houses. In respect with family burial and humankind's preoccupation with dead corpses, the issue of group burial has also probably been existed (Gharavi, 1996: 45). But such group burial has clearly seen in Iron Age in Qom cemetery at Serem Tepe. In this cemetery different kind of graves are available and in one kind the group burial has taken place. Such graves are known as four layers (chahar Chineh) (Talaei, 2013:125).

Further, during Ellam era at Haft-Tapeh courtyard near to sugarcane firm located in the south west of Khozistan Plane, a family burial chamber has found. This building is located in North-West of the tomb complex and West part of Tepti tomb of Ahar in which twenty-three corpses have been buried together in this Tomb (Majidzadeh, 2003:75). In Parthian era and in llemaee state (Khozestasn) near city of Shoshtar (Galalak region), some cellar tombs are found and in one of them seven corpses have buried together (Saeedi Harsini, 1996: 110-111).

As far as the art of architecture is concerned and it is deeply rooted in history, culture and beliefs of people of the times, thus it can be called as the most common art among populace. In architecture, contents and meanings become tangible and found a visible form. Therefore, architecture embodies meanings and it is a medium to illustrate and reflect the identity and culture of a nation as well as a civilization. The art of architecture is one of the significant manifestations of culture in every nation and in every historical period. It is also indicative of human living space (Ghaffari, 1992: 5). However, every representation of beliefs of a nation can be found in architecture.

One of the ancient beliefs of Iranian people and in particular people of Lorestan is to pay respect to their deceased 
ones. Since the old times, Iranian people used to pay respect to their dead relatives and with special rituals and specific methods buried them respectfully (Forozanfar, 1994). They used to build a memorial sign of stone and brick on the graves.

By the advent of Islam, this ancient tradition continued and mingled with Islamic beliefs. The significant of such family crypts is all about that they are not existed only in a specific period of time and faded away by the passage of time, but these crypts and the style and method of burial services have rooted in old history of Lorestan. According to some historical and archeological documents, this tradition used to practice in pre-Islamic era and by the passage of time and emergence of new religions, it has still been continued, and even in contemporary time it is survived. In this article, a scrutiny have executed about historical roots and architectural structure and its implementation in Khizr historical cemetery (Qorbani et al., 2009).

\section{Khizr Historical Cemetery}

Out of several cemeteries in Khoramabad, Khizr is the largest historical cemetery in this city, which is located near the old entrance gate at south; Bajgiran. There is no clear information about historical background of Khizr before advent of Islam. The oldest grave available in this cemetery dates back to $7^{\text {th }}$ Hijir $\left(14^{\text {th }}\right.$.century AD) which belongs to one of the rulers of Atabakans Lor dynasty, named as Jamal-ul-Din Khizr (Mir, 2008:85).

The name of cemetery is taken from the owner of this old grave. Probably this historical area was being used since early Islamic centuries due to its vicinity to Shaberkhast city, which is called Khoramabad today. After historical upheaval in $7^{\text {th }}$ and $8^{\text {th }}$ Hijri, which thereby led to the destruction of Shaberkhast and emergence of Khoramabad in its vicinity, this cemetery became the main burial place for people of Khoramabad. Besides common graves in this cemetery, a number of family tombs named as Lahad and several tombs made of bricks are available which has aggrandized its cultural and historical significant (Fig.1).

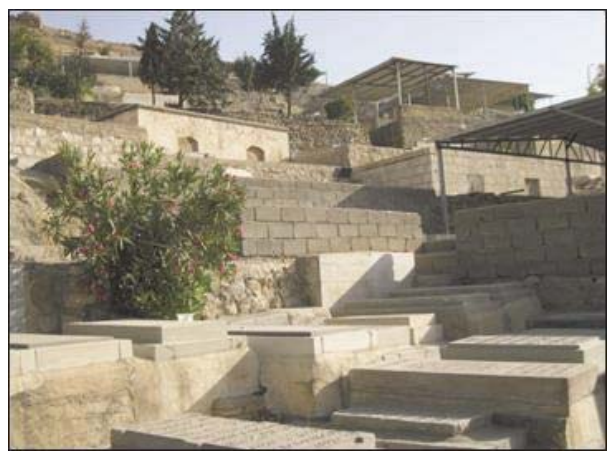

Fig.1: Khizr Historical Cemetery (photo by authors)

\section{Family Tombs named Lahad}

Before discussion about historical roots, structural characteristics and architecture of such buildings, the meaning of word Lahad will be defined. Its origin is Arabic and later entered into Farsi (Persian language). In Abjadi Dictionary of Arabic to Farsi, Lahad means grave and chasm in the ground (Mahyar, 1990:751). In Persian dictionaries Lahad also means grave, tomb, crypt and a grave stone put on the top of it (Amid, 2010: 1025; Sadri Afshar and et al, 2010:2371). In Persian poetry and literature, the meaning of Lahad is almost the same.

In the local custom of Lorestan and people of Khoramabad, Lahad means a small four-walled closed space in which it has a small entry gate and its entrance is a curved shape which made the entry so difficult. The dead corpses are placed inside Lahad on the floor according to Islamic tradition and towards Qibleh (Holy Mecca), and after performing the ritual, the entrance will be blocked and no one is allowed to enter until the next burial ceremony. With respect to slope of the hill, where the cemetery of Khizr is located and this slope makes a right angle with the roof of Lahads, the names of all buried people are inscribed on a "Lahad Stone" which people pilgrimage and recite holy verses for the dead person. The geometrical shape of Lahads is generally square, which is found and constructed in the oblique slope of Khizr 
cemetery. The only entrance to this place, as it was mentioned, is a gate at Eastern side. The walls and the roofs of theses crypts are made by hand, and then the entrance of the crypt has blocked. Sometimes these crypts were built with brick or stone walls and the roof was shaped like cradle arch.

\section{Historical Background of Lahads}

The oldest Lahad, which was found and studied by the authors in Khizr is related to the late Zandiyeh period (18 ${ }^{\text {th }}$ Century). With respect to vanishing of this burial method in Khoramabad (since five decades back) and with the beginning to destruct these Lahads, many of these old chambers were destructed. Some similar examples of such specific method of burial before advent of Islam is related to cemetery of "Behesht Ali" in city of Dezfool (in vicinity to ancient city of Loor, i,e the border of Lor Fili land). In this cemetery, Lahads were also used with some slight differences. Such buildings in North region of Khozistan (Dezfool) was constructed in two models; one is permanent burial chamber (underground), and the other is temporary roofed spaces of burial named as Zac (on ground), which was used for temporary burial and thereby the dead body used to shift to Karbala (Iraq) for permanent burial. The people of Dezfool name this method of burial "Jahfarieh" or "Jafarieh". The family tomb of Ayat-u-llah Mohezi (famous scholar and elite of Dezfool in Safavid and Qajarid era) is an instance of permanent burial chamber in which its architecture is similar to Lahads of Khizr cemetery and similar to burial tradition of Imam's sons underground.

The other burial model; Zac is seen in cemetery of Bhesht Ali in Dezfool. This burial model was a building with two meters long and with one meter width and height, which constructed temporarily on ground with an arc roof of brick.

There is no evidence regarding Lahads in early Islamic centuries, because after passage of several years and emerging signs of damage in them (or many other reasons) they are again repaired. However, many old buildings destroyed, but the trace of such tradition can be seen in Embankment or in Persian word, "Khar-poshteh" graves in old and middle Bronze Age as well as in Parthian period in Lorestan.

With study of pre-Islamic archeological and architectural evidences in region of Lorestan, many instances of specific underground burial have found, which indicate the shape and model of primary Lahads in Islamic era.

During Iran-Iraq war and by an accident two Khar-poshteh graves along with twenty five ancient historical articles (Fig. 2) discovered near village of Gilvaran in route between Khoramabad and Kohdasht city (3 Km away from Khizr cemetery).

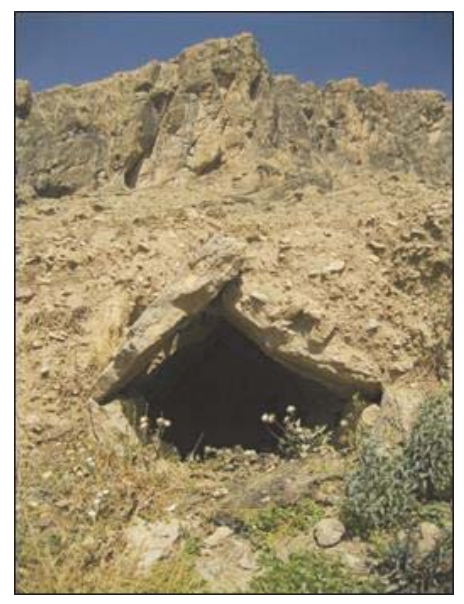

Fig.2: Gilvaran; an embankment grave.(photo by authors).

These graves are like small vestibule with walls and roofs made of stone, which constructed with medium dimensions and they are situated in the slope of mountain. According to the information, archeologists have recommended the time span in the third millennium (between 2400 and 2700) for discovery of these graves (Parviz and Khadish, 2012, 112) (Fig. 3). 


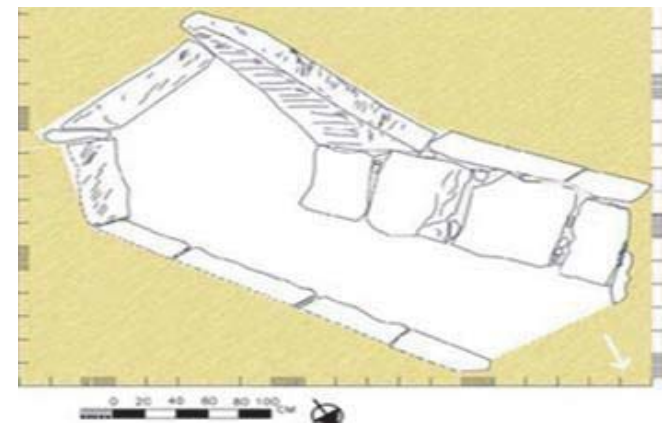

Fig.3: Design and cutting from Gilvaran grave. (Adoptted: Parviz \& Khadish, 2012)

Another example of such specific graves and burial service found in Khar-Poshteh cemetery "Mahical" related to middle Bronze Age in Aligodarz city (Fig.4).

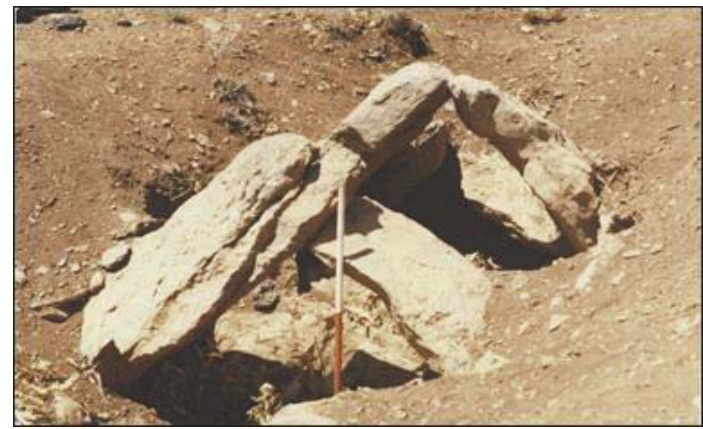

Fig.4: Mahichal embankment grave. (Source: Cultural Heritage Org.)

There are many remained sites such as historical "chemeshk" cemetery in Balagriveh area in Khoramabad, the cemetery of Esmahor village in Shorang area in Aligodarz, Jalalabad site in Aligodarz, Yadegar village which is $40 \mathrm{Km}$ away from Azna district and some other probably undiscovered instances of underground vestibule and Lahak, which it seems that they belong to a specific period, and in particular Ashkanian era in the region of Lorestan. Almost in all aforementioned sites, there has been underground vestibules with length between 5 to 20 meters, width of 1.5 to 2 meters and height of 1.5 to 2 meters, which are dug in ground and to cover the roof of such vestibules for burial big boulders (unsymmetrical cut) with shape of "^", in Persian word "Ghoch-band", have used. So, a roof with slope like a curve is formed which this roof has ultimately been hided within the ground. The way to enter into such vestibules was probably a layer with slope which it was blocked after burial. It seems there was a close relationship between this model of burial and rituals of ancient Iran, and in particular with Mitraism ritual.

Maria Brocious regarding ritual of burial service in his book Ancient Iranians writes, "[In Parth era], ritual of burial service had banned the contact of corpse with soil. Therefore, the corpse was buried in a coffin made of stone" ( Brocious, 2011:162). It is possible that this belief was in association with the kind of burial in stone vestibules. Two instances of such crypts (graves) are Chemeshk and Esmahor.

\subsection{Chemeshk Cemetery}

The crypt of Chemeshk is located in a place named "Meichako" in Poshtang Chemeshk. The distance between the graves is 4 to 5 meters. The earthenware discovered from these graves is related to Parthian era. Besides earthenware, coins and necklaces made of carnelian have found from these graves, which they belong to Acheamenian era (Izadpanah, 1998: 31). 


\subsection{Esmahor Cemetery of Aligodarz}

Esmahor cemetery is known as "Gabriha" in the region (Fig. 5). It is located in Shorang area "Jaapelaq" of Aligodarz upon a hill which is $2 \mathrm{Km}$ away from "Joshan" village. The burial vestibules in this area have a length between 15 to 18 meters. The stones used for the roof of vestibules have a width of 50 to 70 meters and 1.10 to 1.20 meters length and these stones are cut irregularly. Unfortunately, this valuable site has not registered as historical site and in the recent field visit of the authors in March 2015, illegal excavation of unauthorized people can be seen.

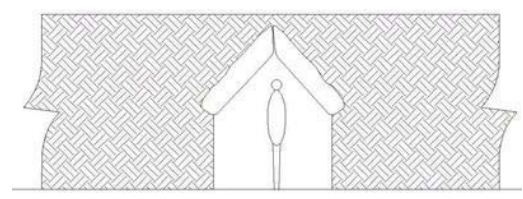

Fig.5: A cut out design of Asmahur grave, Aligodarz. (Drawing by authors)

\section{Architectural Structure of Lahak}

There are three different models of Lahads from architectural perspective and the style of construction.

First model: the main portion of Khizr historical cemetery is located in the foot of a mountain with a sharp slope called "Koohderazeh" and due to resistance of ground, which is hard and stone-made construction of Lahad is feasible. In the past and with knowledge to characteristic of this place, many Lahads are constructed in this hard ground. However, theses chambers are constructed without roof and wall upto 3 to 4 meters width and length and height of 2.5 meters. These chambers are only needed a wall from their Eastern side. Lahads were constructed in this model with a wall in Eastern side and an entry gate in front. In this method of construction, the walls and the roofs (except the Eastern part) have made naturally and were without any decoration.

Second model: in this method the leveling of ground is followed with the construction of Lahad with walls and roof in cradle brick arc shape in approximately 3 to 3.5 meters length and width and height of 2 meters. In the method of construction of Lahad, several chambers could arrange and build cohesively together. No decoration was done in this method except external and internal brick façade.

Third model: this method with respect of some executive necessities and demands was the combination of both first and second model. For example, it could be possible that the walls of Lahad were made of natural stone spontaneously and the roof was made of arc (brick) shape.

In general, the architectural structures of Lahads lack decoration. Basically, inscribing and engraving of holy verses and names of God and Prophet and his family on the stone of Lahads was refused due to unconscious and unintentional walking of people on these stones and disgracing the holy phrases. Instead phrases such as "Shahadatain=an arabic verse from the Holy book of Quran" and "Citing the holy five names" and etc were engraved on stone on the top of entry gate of Lahad.

The entry gate of some Lahak was established with the segments of a flat stone, but in many other cases the entry gate was completely blocked. On the roof of Lahads, one Lahad stone was put in which the name and the owner of buried people was written on it (Figs.6 \&7).

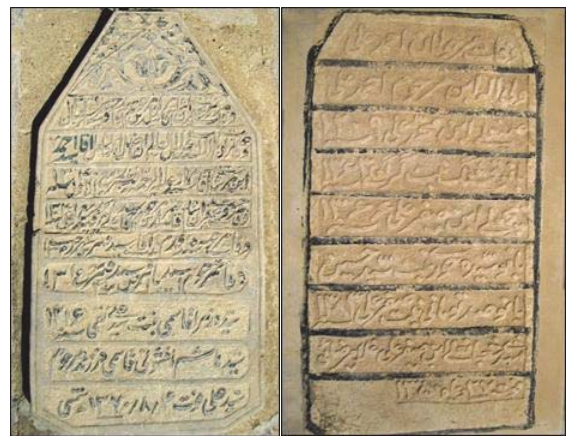

Fig.6 \& 7: Lahad stones (photo by authors) 


\section{Cradle Arc and the Position of Lahad Stone}

In some cases, the names of dead males in the right hand side and the names of females in the left hand side are engraved on Lahad stone. Some Lahad stones at Khizr cemetery are remarkable regarding their decoration and style. Due to annihilation of Lahads in the past and end of burial tradition of corpses in Lahads, no accurate details are available about the number of lahads and their architectural and structural information. But there are still several cases of such burial buildings which are intact or are about to destroy.

In table 1, twenty significant Lahads have mentioned. The oldest one is dated to 1788 AD. and the new one is dated to $1944 \mathrm{AD}$. Out of these numbers, one case belongs to Zandiyeh era, ten cases are related to Qajar era and nine cases are in association with First Pahlavid period.

Table 1. The list of 20 significant Lahads:

\begin{tabular}{|c|l|c|c|c|}
\hline \multirow{2}{*}{ No. } & Name of Lahad & Date of first Burial (H. Q.) & Historical Era & Remarks \\
\cline { 2 - 5 } 1 & Unknown & 1788 & Zandiyeh & \\
\hline 2 & Karbalaei Mohammad Hossain & 1848 & Qajariyeh & 13 names are engraved on its Lahad stone \\
\hline 3 & Karbalaei Akbar & 1883 & Qajariyeh & 11 names are engraved on its Lahad stone \\
\hline 4 & Mola Lotfali Family & 1885 & Qajariyeh & \\
\hline \multirow{2}{*}{5} & $\begin{array}{l}\text { Mashadi Hossain ibn Mashadi } \\
\text { Esmaeil }\end{array}$ & 1901 & Qajariyeh & \\
\hline 6 & Karbalaei Sadeq & 1904 & Qajariyeh & \\
\hline 7 & Keshvari Family & 1909 & Qajariyeh & \\
\hline 8 & Aramideh Family & 1915 & Qajariyeh & \\
\hline 9 & Alimorad Karim Khan & 1921 & Qajariyeh & \\
\hline 10 & Malek Mohammad & 1922 & Qajariyeh & On its Lahad stone is written: "This Lahad \\
\hline 11 & Unknown & 1923 & Qajariyeh & 11 names are engraved on its Lahad stone \\
\hline 12 & Karbalaei Vali & 1926 & First Pahlavid & \\
\hline 13 & Unknown & 1927 & First Pahlavid & \\
\hline 14 & Unknown & 1929 & First Pahlavid & \\
\hline 15 & Unknown & 1931 & First Pahlavid & \\
\hline 16 & Karbalei Mir Mohammad & 1934 & First Pahlavid & \\
\hline 17 & Diseased Alldad ibn Khodadad & 1941 & First Pahlavid & \\
\hline 18 & Farkhani Family & 1942 & First Pahlavid & \\
\hline 19 & Mashadi Rostam Galehdar & 1944 & First Pahlavid & \\
\hline 20 & Mashadi Ali ibn Alidad & 1945 & First Pahlavid & \\
\hline
\end{tabular}

\section{Discussion}

The survey and study of Lahads at Khizr cemetery in Khormabad have four challengeable issues. First problem is related to the relationship between Lahads belong to Islamic period in Khoramabad and group burial service in pre-Islamic era in this region and other areas.

The second problem raises the question about the culture of making Lahad at Khizr cemetery whether it was a local culture of Lorestan or a foreign and borrowed one from other areas. Third issue is about Lahad's social function, its benefits and the cause of its continuity in construction.

To answer the first question, it should be mention that one of the significant characteristics of Lahads in Khoramabad is about their potential of receiving ongoing and constant dead bodies. This tradition in which a grave used to be consumed several times has been practiced since ancient days in Iran. Nevertheless, in Serum Cemetery at Qom, which it belongs to Iron Age this kind of burial, which is based on group or family burial have been seen. This model of burial is called "Four-layers". The dead body was located inside a small four-walled made of sun-dried brick. In this model of graves, no movement takes place regarding previous burial and new dead arrivals are entered without any displacement in the articles related to previous dead bodies. This characteristic of group burial has seen in ancient IIlam era. For instance, one group burial case is available in the West of Tepti-Ahar tomb. This tomb which was found in Haft- 
Tapeh is entirely made of brick and has X-junction arc. The dimensions of tomb are $1.65^{\star} 1.85^{\star} 4.80$. Twenty three dead bodies are buried in this tomb. In Parthian era, crypt-like-tombs was used for group burial. For example, in Shoshtar in Destova region, some crypt-like-tombs were found in which one has many steps in its entrance. Each of these tombs has three stages which on every stage one earthen coffin is located. Beneath the stages were usually empty and corpses buried inside them. Under one of the stages, seven corpses which were laid in different directions have been identified. In Islamic period which group burial has not been in conflict with Islamic tradition and customs, people of Lorestan continued the tradition of their ancestors and buried the dead bodies inside the Lahad and it still continues.

Regarding indigenousness or non-native of Khoramabad's Lahads, it should be noted that with respect of field work of authors only in two places of Lorestan Fili that is Khoramabad and Dezfool, this model of burial has been found. Since Zandiyeh era until some decades ago this burial model at Khizr cemetery in Khoramabad has been continued. In Dezfool at Behesht Ali cemetery, similar instances of Khoramabad's Lahads have found in which their structure and application are same. But in some part of Lorestan, different models of burial have been found, which Khoramabad's Lahads probably took example from them. This model of burial consisted of underground tunnels which their roofs are designed with flat boulders in Qochband style. Of this model of burial, Khar-poshtie grave is referred to in Gilvaran village, which is $2 \mathrm{Km}$ away from Khizr and with respect of remained articles with the dead bodies, experts estimated its oldness to Bronze Age. Specific model of chambers, underground corridors and vestibules for burial have remained in historical cemetery of Chemeshk at Balagriveh of Khoramabad, cemetery of Esmahoor village at Shorang of Aligodarz and cemetery of Yadegar village near Azna, which they all belong to one exclusive era and in particular Parthian period in region of Lorestan.

Regarding social function and the cause of continuation of making Lahads during the history, some significant factors such as affinity with burial style in ancient Iran can take into consideration. However, Lahad has old history and its emergence related to the old times. On the other hand, the way to bury a dead body into Lahad is in contraction with the way a dead body buries in Islam. In Islam, the dead bodies should be buried in a grave with certain depth and the grave should be covered by soil, but it is not so in Lahad. In Lahad, the dead bodies are taken into it and they are laid on the ground without being buried underground. To give same example in this regard in ancient Iran and its history, we can refer to crypts in the time of Mades and Acheamenian. In that time and according to Zoroastrian instructions, a dead corpse was supposed impure, and four scared elements_Akhshij_ (water, wind, soil, fire) should not stained with impurities. Due to this reason, the dead bodies were not supposed either to burn or to bury underground or located in the open areas in front of wind or to be thrown into water. But the corpses were taken into a building entirely made of stone named as Borje Khamoshan. After decay and decomposition of body, its bones are collected and they are shifted to a place called Stowdan. It is likely that these Lahads are a memorial from ancient time and there are simulated to the crypts in the time of Medes and Acheamenian. Covering and coating the building with stones was due to the preservation of the Akhshij (four elements) from pollution. Whereas making crypts and digging the mountain have been a difficult job and it was not feasible for everyone, therefore, that method was replaced by making Lahad (Rastegarfard, 2004).

Another factor is a custom which was widespread among Lor peoples. This custom is about a couple who used to live together for years. If each of the couple has not made a will regarding the place of burial after their death, they are taken to paternal cemetery and buried next to their ancestors and siblings. However, the importance and seriousness of the segments of ground that every family assigns to his cemetery is comparable with preservation and protection of land, home and State. In ancient Iran and before Islam, the culture of group burial has been practiced and almost a specific history for its emergence cannot be cited. After advent of Islam and as this method of burial was not in contradiction with Islamic instructions, people of Lorestan to some extent continued to bury their dead bodies since then. In the past time, the owner of Lahad was in connection with prestige and urbanism. Thus the noble families of Khoramabad used to follow this method of burial. Today, most of the families who were inhabited in Khoramabad for several generations use Lahad for burial. The advantage of these collective graves is gathering all members of a family in a tomb in which every family assign a certain place to themselves and others were not supposed to bury their relatives. In addition to this factor, emotional factor cannot be ignored in making such group graves. It seems that with respect of belief to the life after this mundane life, man likes to be with his love's one hereafter.

\section{Conclusion}

The output achieved from this research is scrutinized in three distinct discussions. First, this kind of graves is located in cultural domain of Lorestan which is consisted of today's Lorestan and other Lor neighboring provinces. The reason to mention the former phrase is Behesht Ali cemetery in Dezfool, located in North of Khozistan and the only place which it has similar instances of Khoramabad's Lahads. In addition, a kind of burial related to Bronze Age has been found in 
Gilvaran village which is located in Khizr cemetery and it is similar to Lahads of Khizr as they are considered to instances of Lahads at Khizr. Two instances of such graves are discovered as they are built like tunnel and they have a roof made of stone which connected together with curve arc and Khar-poshtei style. Their similarity with Lahads is about their domestic space in which the corpse is buried inside a compartment without contact to soil. Perhaps this model of burial is in association with Zoroastrian and their dissatisfaction to pollute the soil. Besides Gilvaran in Aligodarz and other areas in Lorestan and Iran, some Khar-poshtei graves are found which indicates that Khoramabad's Lahads are dated back to pre-Islamic era.

Second result is about Lahad's use and its social function. Lahads of Khoramabad are history and identity for families in Khoramabad because all dead people of a family are buried in group and if a young individual has decided to learn about the diseased ones in the family, he should have contacted to the family Lahad stone in order to gain all information. In the other hand, this Lahad stone was a history of family and this model of burial caused an emotional connection between members of family.

Third discussion is about relationship between Lahads of Islamic era in Lorestan and pre-Islamic group tombs. There is one main reason which led to construction of family and group tombs in Lorestan fili. This reason should be examined in the old background of tomb making because such collective tombs have found in different ancient and historical era of Iran. For example, in Serum cemetery of Qom related to Iron Age, there are collective tombs of middle Illam located next to Tapti-Ahar in Haft Tapeh and catacombs graves of Destova in Shoshtar related to Parti era. In fact, aforementioned examples indicate that the people of Lorestan in ancient time have been familiar with burial group and after advent of Islam to Iran, this burial method continued because it was not in conflict with Islamic instructions. Actually the architecture of Lahads which is available in Lorestan now is innovatory of Lorestan people and this kind of architecture is only available in Khoramabad and to some extent in Dezfool. Therefore, people of Lorestan with the help of old background of family tombs and taking idea from them and also with the use of local architecture, created a model of family burial which it has many benefits for them.

\section{References}

Amid, H. (2010). Amid Persian Dictionary. (Persian). Tehran: Ashjaa.

Brocious, M. (2011). Iranian Ancient Times. Translated into Persian by H. Mashayekhi. Tehran: Hermes.

Forozanfar, B. (1994). Shams-e Tabrizi. (Persian). Qum: Boostan Ketab.

Ghaffari, A. (1992). Zavareh; The Symbol of Kavir Myth. (Persian). Pezohesh Farhangi.

Gharavi, M. (1996). Tomb in Iranian Culture. (Persian). Tehran: Anjoman Mafakher.

Izadpanah, H. (1998). Lorestan Ancient And Historical Monuments. (Persian). (3rd. ed.). Tehran: Anjoman Mafakher.

Jaavid, H. \& Khoramshahi, B. (1990). Hafiz. (Persian). Tehran: Farzan.

Mahyar, R. (1990). Abjadi Dictionary. (Persian). Tehran: Islamic Publications.

Majidzadeh, Y. (2003). History and Civilization of Illam, (Persian). Tehran: A Center for Universitiy Books Publications.

Mir, N. (2008). Five Hundred Years History of Lorestan. (Persian). Khoramabad: Shahpoorkhast.

Mohamadi, M. (2010). The Memories of Mine from Ancient Khoramabad. (Persian).Aflak Press.

Parviz, A. \& Khedish, P. (2012). The Royal Tombs of Bronze Age in Gilvaran, Khoramabad. Journal of Archaeological Research. (Persian). 4:8, 110-116.

Qorbani, R. Et al. (2009). The Indices of Islamic Architecture and Urbanism. (Persian). Tehran: Markaz Nashr Press.

Rastegarfard, Ahad, (2004), The Burials and Religious Ceremonies in Lorestan. [Online] Available: http://www.Khormoa.persianblog.ir/post (Jan. 18, 2004)

Sadri Afshar, G. et al. (2010). Persian Encyclopeadia. (Persian). 3rd.vol. Tehran: Farhang-e Moaaser.

Saeedi Harsini, M.R. (1996). The Survey of Burial Method During Parthian Dynasty. (Persian). Tehran: Moddares University. 